\title{
Stimulation of the Proliferation of Human Bone Cells In Vitro by Human Monocyte Products with Interleukin-1 Activity
}

\author{
Maxine Gowen, David D. Wood, and R. Graham G. Russell \\ Department of Human Metabolism and Clinical Biochemistry, Sheffield University Medical School, Sheffield, England; and Department \\ of Immunology and Cell Biology, Ayerst Laboratories Research Inc., Princeton, New Jersey 08540
}

\begin{abstract}
The process of induction of bone formation, which follows bone resorption during normal and pathological bone turnover, is well documented. However, the mechanisms responsible for this process are unclear. Mononuclear phagocytes present at the sites of bone remodeling could play a role in this "coupling" of bone formation to bone resorption. This study was designed to investigate such a possibility. By measuring both the increase in $\left.{ }^{3} \mathrm{H}\right]$ thymidine incorporation and in cell number, we found that human monocytes in culture released factors capable of stimulating the proliferation of osteoblast-like cells derived from human bone. Rapidly dividing cells exhibited a greater response to interleukin 1 (IL-1) than confluent cells.

The factors are similar to IL-1 in that they exhibited the same molecular weight and isoelectric point, were present in fractions that contained IL-1 activity after gel filtration chromatography and isoelectric focusing, and showed similar doseresponse characteristics. Proliferation was more marked when prostaglandin production by the cells, which was also stimulated by these factors, was inhibited by indomethacin.

A factor produced by monocytes that affects osteoblast activity may be important in the coupling of osteoclast and osteoblast actions.
\end{abstract}

\section{Introduction}

Local mechanisms of bone regulation that induce "coupling" of the processes of bone resorption and bone formation depend on recruitment of osteoblasts or their precursors to the sites of bone resorption and their subsequent proliferation. Baron et al. (1) have shown that mononuclear cells appear at sites of bone remodeling in the reversal phase, the "resting" phase between bone resorption and new bone formation. It is possible that these cells play a role in the recruitment and activity of osteoblast precursors. The necessity for monocyte/macrophages to be present at sites of wound healing has been well documented, and many factors derived from these cells have been reported to affect either the protein synthesis of fibroblasts or their proliferation (2-9). While these studies have demonstrated interesting and important effects of monocyte products on mesenchymal cell growth, little is known of the molecules

Address correspondence to Dr. Gowen, Department of Medicine, Division of Endocrinology, University of Texas Health Science Center at San Antonio, 7703 Floyd Curl Dr., San Antonio, TX 78284.

Received for publication 12 July 1984 and in revised form 10 October 1984.

J. Clin. Invest.

(c) The American Society for Clinical Investigation, Inc.

0021-9738/85/04/1223/07 \$1.00

Volume 75, April 1985, 1223-1229 responsible for these activities. The aims of this study were to investigate the ability of partially purified interleukin 1 (IL1), ${ }^{1}$ previously shown to stimulate collagenase and prostaglandin production by chondrocytes (10) and bone resorption (11), to stimulate osteoblast proliferation.

\section{Methods}

Bone cell culture. Small explants $\left(3 \mathrm{~mm}^{2}\right)$ of human trabecular bone were removed, gently scraped and washed free of soft tissue and marrow, and placed in 9-cm tissue culture dishes with Eagle's minimal essential medium (MEM; Gibco Laboratories, Paisley, Scotland) + $10 \%$ fetal calf serum (FCS). After $\sim 7 \mathrm{~d}$ cells began to grow out from the explants, and by 20-30 d they were confluent and ready for use. Cells were always taken from primary cultures (first passage) and were kept in contact with the bone chips until their transfer into multiwells. Bone fragments were then transferred to fresh culture dishes where a second population of cells was obtained.

These cells have been extensively characterized and exhibit many classical osteoblastic activities (12). They produced cyclic AMP (cAMP) in response to parathyroid hormone, synthesize type I collagen and glycosaminoglycans, and produce prostaglandins, alkaline phosphatase, and the bone-specific protein osteocalcin (13). The synthetic functions can be modulated by parathyroid hormone and 1,25-dihydroxyvitamin $D_{3}(13,14)$. When treated with 1,25 -dihydroxyvitamin $D_{3}$ all cell lines used in the studies described here produced osteocalcin and alkaline phosphatase, both of which are widely accepted as osteoblast markers. These cells differ from stromal fibroblasts cultured from the marrow in a number of ways, particularly in the inability of the latter to synthesize osteocalcin.

Production and purification of $I L-1$. The production of IL-1 by human monocytes has been described elsewhere (15). Briefly, IL-1 was prepared by culturing adherent cells from $10^{6}$ mononuclear human blood cells from normal donors in $1 \mathrm{ml}$ RPMI $1640+1 \%$ FCS. Larger amounts of IL-1 were prepared by culturing leukocytes from patients with chronic myelomonocytic leukemia in the same medium. In the latter case cells from the leukophoresis were washed, adjusted to a concentration of $2-5 \times 10^{7}$ leukocytes $/ \mathrm{ml}$, and cultured without further fractionation. In this case monocytes accounted for $80 \%$ of the leukocytes. All cultures were stimulated with $0.1 \mu \mathrm{g} / \mathrm{ml}$ of Escherichia coli 0111:B4 endotoxin. Supernatants were collected after $24 \mathrm{~h}$, centrifuged to remove cellular debris, and stored at $-70^{\circ} \mathrm{C}$. The supernatants lack $\mathrm{T}$ cell growth factor activity (interleukin 2 ) as judged by assay on CT6 cells (16). Partial purification of the IL-1 activity by Sephadex G75 gel filtration and isoelectric focusing in a sucrose gradient have been described in detail previously (15).

Lymphocyte activating factor (LAF) assay. The activity of the IL1 preparations was measured by the LAF assay as described previously (17). Briefly, $1.3 \times 10^{6}$ thymocytes from $\mathrm{C} 3 \mathrm{H} / \mathrm{HeJ}$ mice were cultured for $72 \mathrm{~h}$ in $0.2 \mathrm{ml}$ RPMI 1640 supplemented with gentamicin, 2.5 $\times 10^{-5} \mathrm{M}$ 2-mercaptoethanol, $0.5 \mu \mathrm{l} / \mathrm{ml}$ phytohemagglutinin, and $5 \%$ FCS, in 96-microwell trays. The cultures were pulsed for the final 4-6 h with $0.5 \mu \mathrm{Ci}$ of $55 \mathrm{Ci} / \mathrm{mmol}\left[{ }^{3} \mathrm{H}\right]$ thymidine and harvested with a

1. Abbreviations used in this paper: FCS, fetal calf serum; IL-1, interleukin 1; LAF, lymphocyte activating factor; MEM, minimal essential medium; pI, isoelectric point. 
MASH II automatic cell harvester (Microbiological Associates, Walkersville, MD). LAF activity was expressed as counts per minute of $\left[{ }^{3} \mathrm{H}\right]$ thymidine incorporation.

$\left[{ }^{3} \mathrm{H}\right]$ Thymidine incorporation into bone cells. One method of measuring the incorporation of $\left[{ }^{3} \mathrm{H}\right]$ thymidine into cells was used for the experiment shown in Fig. 1 and then substantially modified for subsequent experiments. The original method is described in detail in the legend to Fig. 1.

Cells were passaged into $1.4-\mathrm{cm}$ wells containing $0.55 \mathrm{ml}$ MEM $+10 \%$ FCS at a density of $1.25-2.0 \times 10^{4}$ cells/well. Cells were left for 1 or $2 \mathrm{~d}$ to allow for recovery from trypsinization. Medium was removed, the cell layers were washed twice with phosphate-buffered saline (PBS), and $0.5 \mathrm{ml}$ MEM containing serum and test substances was added to each well. $6 \mathrm{~h}$ before removal of medium $(66 \mathrm{~h}$ after addition of IL-1, unless otherwise stated) $1 \mu \mathrm{Ci}$ of $6-\left[{ }^{3} \mathrm{H}\right]$ thymidine in $50 \mu \mathrm{l}$ of the appropriate culture medium was added to each well. At the end of the incubation, medium was removed and discarded, and cell layers were washed.

$0.25 \mathrm{ml}$ of $0.25 \%$ (wt/vol) trypsin solution was added to each well. Plates were placed in a $37^{\circ} \mathrm{C}$ incubator for $20-30 \mathrm{~min}$, by which time the cell layer was removed. The wells were washed with a total volume of $0.75 \mathrm{ml}$ water which was then added to the cell suspension. $50 \mu \mathrm{l}$ FCS and $100 \mu \mathrm{l}$ of $60 \%$ TCA were added to the tubes, which were left on ice for between 3 and $18 \mathrm{~h}$. The mixture was then centrifuged at $2,000 \mathrm{~g}$ for $10 \mathrm{~min}$ at $4^{\circ} \mathrm{C}$. The supernatant was removed by aspiration, $1 \mathrm{ml}$ water was added, and the precipitate was allowed to redissolve at room temperature. The precipitation step was repeated, the final precipitate was redissolved in $0.5 \mathrm{ml}$ water and $4 \mathrm{ml}$ scintillant, and the $\left[{ }^{3} \mathrm{H}\right]$ thymidine in the solution was measured using a Rackbeta liquid scintillation counter (model 1218; LKB Instruments, Gaithersburg, MD) with an automatic disintegrations per minute program.

Cell counting. Cells were passaged into $1.4-\mathrm{cm}$ wells containing $0.55 \mathrm{ml}$ MEM $+10 \%$ FCS at a density of $1.5 \times 10^{4}$ cells/well. The next day they were seen to be quite sparse and evenly distributed over the wells. Medium was then replaced with MEM containing 3\% FCS, $1.4 \times 10^{-6} \mathrm{M}$ indomethacin, and $\mathrm{IL}-1$ at the concentrations indicated. At this time the cells from four wells were removed for counting by adding $200 \mu \mathrm{l}$ of $0.25 \%$ trypsin/0.02\% EDTA solution and incubating for $5-10 \mathrm{~min}$ at $37^{\circ} \mathrm{C}$. The cell suspension was put into a $1.5-\mathrm{ml}$ conical microfuge tube, the wells were washed with $2 \times 0.4 \mathrm{ml}$ MEM $+10 \%$ FCS, and the cells were harvested by centrifugation at $200 \mathrm{~g}$ for $5 \mathrm{~min}$ in a microcentrifuge (Beckman Instruments, Inc., Fullerton, CA). The cell pellet was resuspended in $0.25 \mathrm{ml}$ MEM $+10 \%$ FCS. In experiment 1 the cells were counted using a hemocytometer; the number of cells in 10 fields was counted. In experiment 2 , resuspended cells were mixed with Isoton and counted in a Coulter counter (Coulter Electronics, Inc., Hialeah, FL). Cells remaining in the wells at the end of the 72-h culture period were removed and counted as described above. The increase in the number of the cells was calculated by subtracting the 0-h figures from the 72-h figure. A ratio of the number of treated to control cells was then calculated as a measure of the stimulation.

Statistics. Differences between treatments were determined using analysis of variance.

\section{Results}

Partially purified monocyte products stimulated the incorporation of $\left[{ }^{3} \mathrm{H}\right]$ thymidine into bone cells at dilutions between 0.02 and $0.5 \%$ (Fig. 1), but errors were large using this original method, so differences between control and treated cells were not very marked. However, a linear log dose-response to IL-1 was achieved in the presence of indomethacin (Fig. 1). This indicates that IL-1-stimulated prostaglandin production (10) inhibits bone cell DNA synthesis; when this effect is abolished the DNA-stimulating activity of IL-1 is unmasked. Preliminary experiments have shown that prostaglandin $E_{2}(2-200 \mathrm{ng} / \mathrm{ml})$

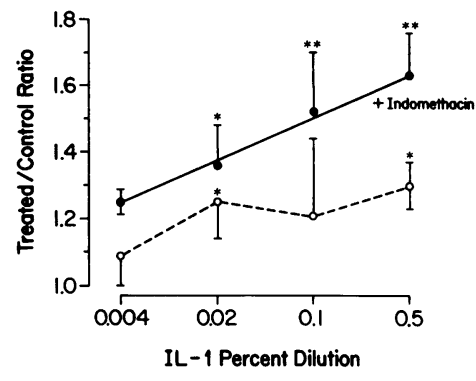

Figure 1. Effect of IL-1 and indomethacin on DNA synthesis by human bone cells in vitro. Cells were seeded on 3-cm multiwells at a density of $3 \times 10^{4}$ cells/well. After $3 \mathrm{~d} 15 / 5.6$ IL-1 was added at the dilutions indicated in the presence or absence of 1.4 $\times 10^{-6} \mathrm{M}$ indomethacin, in a total volume of $1 \mathrm{ml}$. After $18 \mathrm{~h} 2 \mu \mathrm{Ci}$ of $6-\left[{ }^{3} \mathrm{H}\right]$ thymidine in $50 \mu \mathrm{l}$ of medium was added to each well. After $6 \mathrm{~h}$ the medium was removed and discarded, and the cell layer was washed three times with PBS. Cell layers were removed by scraping after $1 \mathrm{ml}$ of $0.1 \%$ Triton had been added to each well. The scraper and well were washed with a total of $1 \mathrm{ml}$ ice-cold water, and the washings were added to the Triton suspension. To $1 \mathrm{ml}$ of this suspension was added $0.1 \mathrm{ml}$ of bovine serum albumin solution $\left(10 \mathrm{mg} / \mathrm{ml}^{-1}\right.$ in water) as carrier, and $0.15 \mathrm{ml}$ of $60 \%$ TCA (final concentration 7.2\%). The contents of the tubes were mixed and allowed to stand on ice for at least $1 \mathrm{~h}$. The procedure was then as described in Methods. Incorporation of control cells without indomethacin was

$57,797 \pm 5,795 \mathrm{dpm} /$ well, and with indomethacin was $58,159 \pm 5,502$ $\mathrm{dpm} /$ well. Values shown are means \pm SEM for six (control) or five (treated) replicate wells. Open circles, without indomethacin; closed circles, with indomethacin. (*), $P<0.05 ;(*), P<0.01$.

inhibits $\left[{ }^{3} \mathrm{H}\right]$ thymidine incorporation by bone cells (unpublished data). All following experiments were, therefore, carried out in the presence of $1.4 \times 10^{-6} \mathrm{M}$ indomethacin, which reduced prostaglandin synthesis to undetectable levels $(<20 \mathrm{pg} / \mathrm{ml})$.

Several experiments were performed to optimize the assay conditions before further investigation of the nature of the growth factor. The optimal serum concentration for a 72-h incubation, when treated/control ratios were highest, was found to be $3.3 \%$ (Table I). However, when a 24-h incubation was used, $10 \%$ serum was the most effective addition. The results of the 24-h incubation with $10 \%$ FCS and IL-1 are very similar to those of the corresponding experiment shown in Fig. 1. Serum concentration and incubation time were thus set at $3 \%$ and $72 \mathrm{~h}$, respectively, for subsequent assays.

We evaluated the proliferative response of preconfluent and confluent cells to IL-1. Cells were passaged into multiwells and divided into two groups. After $24 \mathrm{~h}$ in culture, IL-1containing medium was added to group 1 cells and the assay carried out as described. By day 6 the cells in group 2 were confluent. The experiment was repeated using these cells, and the results are shown in Fig. 2. Time points corresponded to the periods immediately before and after the log phase of growth, as determined in other experiments. The response to IL-1 is clearly greater before cells enter the log phase of growth than after they complete it. Although a dose-responsive effect is seen in both cases, the maximum treated/control ratio of preconfluent cells is $4.4 \pm 0.08$, compared with $2.34 \pm 0.14$ for confluent cells. Increased proliferation of actively growing cells has not been reported in similar studies by other workers (18). This may be relevant when interpreting such increases in terms of proliferation of precursor cell populations in sites where confluent cells are not already present, as in the bone remodeling cavity.

Fig. 3 shows the results of two experiments that tested whether the addition of IL-1 to bone cells would result in an 
Table I. Effect of Varying Incubation Time and Serum Concentration on Changes in DNA Synthesis by Human Bone Cells in Response to IL-1

\begin{tabular}{|c|c|c|c|c|c|c|c|}
\hline \multirow[b]{3}{*}{ Serum } & \multirow[b]{3}{*}{ IL-1 dilution } & \multicolumn{6}{|c|}{$\mathrm{T} / \mathrm{C}$ ratios } \\
\hline & & \multicolumn{2}{|l|}{$24 \mathrm{~h}$} & \multicolumn{2}{|l|}{$48 \mathrm{~h}$} & \multicolumn{2}{|l|}{$72 \mathrm{~h}$} \\
\hline & & Mean & SEM & Mean & SEM & Mean & SEM \\
\hline$\%$ & $\%$ & & & & & & \\
\hline \multirow[t]{3}{*}{1.0} & 0.008 & 1.27 & $0.06^{*}$ & 1.56 & $0.07 \ddagger$ & 2.04 & $0.11^{*}$ \\
\hline & 0.040 & 1.46 & $0.04 \S$ & 1.30 & $0.11^{*}$ & 3.09 & $0.31^{*}$ \\
\hline & 0.200 & 0.90 & 0.07 & 2.01 & $0.11 \S$ & 2.93 & $0.64 \ddagger$ \\
\hline \multirow[t]{3}{*}{3.3} & 0.008 & 1.15 & 0.03 & 1.36 & $0.07^{*}$ & 2.20 & $0.10 \ddagger$ \\
\hline & 0.040 & 1.19 & 0.05 & 1.70 & $0.12 \S$ & 2.64 & $0.33 \S$ \\
\hline & 0.200 & 1.20 & 0.08 & 2.02 & $0.09 \S$ & 3.07 & $0.18 \S$ \\
\hline \multirow[t]{4}{*}{10.0} & 0.008 & 1.19 & 0.08 & 1.05 & 0.19 & 1.37 & 0.18 \\
\hline & 0.040 & 1.45 & $0.06 \ddagger$ & 1.41 & $0.05^{*}$ & 1.80 & 0.05 \\
\hline & 0.200 & 1.55 & $0.14 \ddagger$ & 1.28 & $0.06^{*}$ & 2.07 & $0.19 \S$ \\
\hline & & \multicolumn{6}{|c|}{$\left[{ }^{3} \mathrm{H}\right]$ Thymidine incorporation $\left(\mathrm{dpm} /\right.$ well) $\times 10^{-3}$} \\
\hline 1.0 & 0 & 156 & 12.7 & 14.4 & 1.31 & 5.32 & 1.40 \\
\hline 3.3 & 0 & 196 & 16.6 & 32.9 & 4.19 & 13.6 & 2.06 \\
\hline 10.0 & 0 & 139 & 17.2 & 67.2 & 3.32 & 42.9 & 3.48 \\
\hline
\end{tabular}

Bone cells were cultured in 1.4-cm multiwells with $0.5 \mathrm{ml}$ of MEM $+1.4 \mathrm{M}$ indomethacin with FCS and 35/7.1 IL-1 at the concentrations indicated. $1 \mu \mathrm{Ci}$ of $\left[{ }^{3} \mathrm{H}\right]$ thymidine was added to wells at 18,42 , and $66 \mathrm{~h}$, respectively, and incubations continued for another $6 \mathrm{~h}$. Values are expressed as means \pm SEM of ratios of treated/control cells for four replicate determinations. $\left[{ }^{3} \mathrm{H}\right]$ Thymidine incorporation of control cells is shown in the lower half of the table. ${ }^{*} P<0.05$. $¥ P<0.01$. $\S P<0.001$.

increase in cell number as well as in DNA synthesis. In each experiment, two groups of cells were treated identically, except that to one group was added $\left[{ }^{3} \mathrm{H}\right]$ thymidine $6 \mathrm{~h}$ before the end of incubation, and incorporation was measured as described before. The other group of cells was carefully removed from the wells and counted using either a hemocytometer (experiment

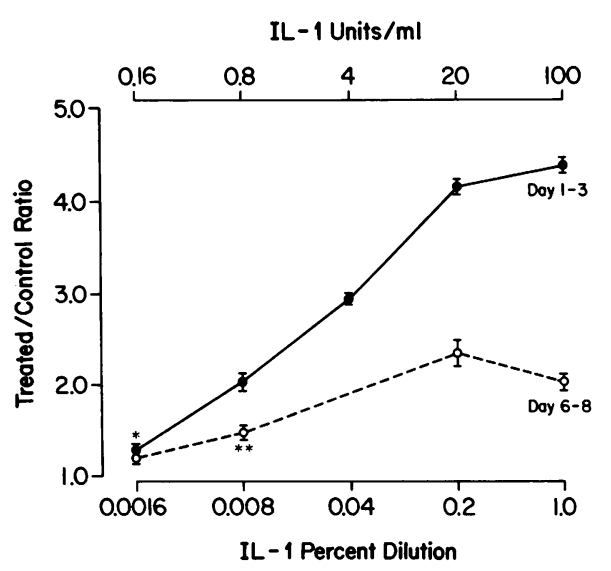

Figure 2. Effect of IL-1 on DNA synthesis by preconfluent and confluent human bone cells in vitro. Bone cells were passaged into 1.4-cm wells at a density of $2 \times 10^{4}$ cells/well. $\left[{ }^{3} \mathrm{H}\right]$ Thymidine incorporation is expressed as a ratio of treated/control cells. Incorporation of control cells on day 1 was $2,274 \pm 168 \mathrm{dpm} /$ well, and on day 6 was $2,438 \pm 170 \mathrm{dpm} /$ well. Values shown are means \pm SEM for four replicate determinations. All points are significantly different from control $P<1 \times 10^{-7}$, except for those indicated. (*), $P<0.05$; $(*), P<0.01$.
1) or a Coulter counter (experiment 2). Results are expressed as treated/control ratios of the change in cell number over 72 h. In both cases an increase in $\left.{ }^{3} \mathrm{H}\right]$ thymidine incorporation accompanied the increase in cell number (Table II). It was

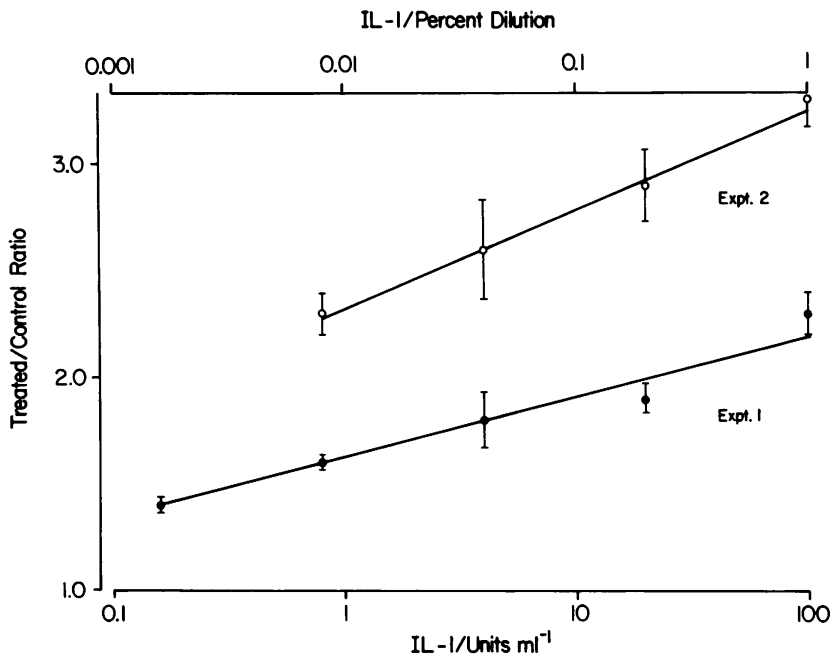

Figure 3. Effect of IL-1 on number of human bone cells in vitro. Cells were passaged into 1.4-cm wells at a density of $1.5 \times 10^{4}$ cells/ well. After 1 (experiment 1 ) or 2 (experiment 2 ) d the medium was replaced with $0.5 \mathrm{ml} \mathrm{MEM}+3 \% \mathrm{FCS}+1.4 \times 10^{-6} \mathrm{M}$ indomethacin and 15/7.1 IL-1 at the concentrations indicated. After $72 \mathrm{~h}$ the cells were counted, as described in the text. Effects are expressed as ratios of treated/control wells, and are means \pm SEM for four replicate determinations. 
Table II. Effect of IL-I on $\left[{ }^{3} \mathrm{H}\right]$ Thymidine Incorporation and Cell Number of Human Bone Cells In Vitro

\begin{tabular}{llllll}
\hline & \multicolumn{2}{l}{ Cell number } & & \multicolumn{2}{l}{$\left.{ }^{3} \mathrm{H}\right]$ Thymidine } \\
\cline { 2 - 2 } \cline { 5 - 6 } IL-1 dilution & Mean & SEM & & Mean & SEM \\
\hline$\%$ & & & & \\
Experiment 1 & & & & \\
0 & 1.0 & & & 1.0 & \\
0.008 & 2.3 & 0.09 & 2.6 & 0.11 \\
0.040 & 2.6 & 0.25 & 3.8 & 0.17 \\
0.200 & 2.9 & 0.18 & & 4.6 & 0.20 \\
1.000 & $3 . ?$ & 0.15 & 5.0 & 0.19 \\
Experiment 2 & & & & \\
0 & 1.0 & & & \\
0.0016 & 1.4 & 0.03 & 1.0 & 0.04 \\
0.008 & 1.6 & 0.03 & 1.9 & 0.08 \\
0.040 & 1.8 & 0.13 & 2.8 & 0.11 \\
0.200 & 1.9 & 0.07 & 2.9 & 0.02 \\
1.000 & 2.3 & 0.10 & 2.9 & 0.31 \\
& & & & & \\
\hline
\end{tabular}

Cells were passaged into $1.4-\mathrm{cm}$ wells at a density of $1.5 \times 10^{4}$ cells/ well. After 1 (experiment 1 ) or 2 (experiment 2 ) $d$ the medium was replaced with $0.5 \mathrm{ml} \mathrm{MEM}+3 \%$ FCS $+1.4 \times 10^{-6} \mathrm{M}$ indomethacin and 15/7.1 IL-1 at the concentrations indicated. After $72 \mathrm{~h}$ onehalf of the cells were counted, as described in the text, and the other was treated as before, by adding $\left[{ }^{3} \mathrm{H}\right]$ thymidine for $6 \mathrm{~h}$. Effects are expressed as ratios of treated/control wells, and are means \pm SEM for four replicate determinations.

therefore possible to use the convenient and sensitive $\left[{ }^{3} \mathrm{H}\right]$ thymidine incorporation assay as a measure of bone cell proliferation.

The results obtained using these two methods showed a good correlation, particularly since they measured different time periods. The amount of $\left[{ }^{3} \mathrm{H}\right]$ thymidine incorporation per cell was also dependent on the cell cycle, since cells incorporated $\left[{ }^{3} \mathrm{H}\right]$ thymidine in the $S$ phase and did not reach the $M$ phase before the end of the experiment. The amount of labeled DNA did not, therefore, directly represent the number of cells. It is also possible that a subpopulation of the cells is stimulated to divide, as is the case when IL-1 stimulates thymocyte $\left[{ }^{3} \mathrm{H}\right]$ thymidine incorporation. DNA synthesis would not then correspond exactly with cell number.

It was also important to determine whether the factor that stimulated thymidine incorporation could sustain the growth of cells in serum-free medium. An experiment was carried out to compare the effect of IL-1 on bone cells in serum-free medium at $72 \mathrm{~h}$ after the addition of factor with cells in medium containing $3 \%$ serum as a positive control. Fig. 4 shows that the cells were responding normally to IL- 1 in serum-containing medium, and that by $72 \mathrm{~h}$ a similar stimulatory effect of IL-1 was seen in both sets of cells. The results indicate that the factor responsible for increased $\left[{ }^{3} \mathrm{H}\right]$ thymidine incorporation into the bone cells was itself a growth factor in that it supported the proliferation of the cells in serum-free medium. The factor also stimulated the proliferation of skin cells but inhibited DNA synthesis in chondrocytes derived from the same patient (unpublished data).

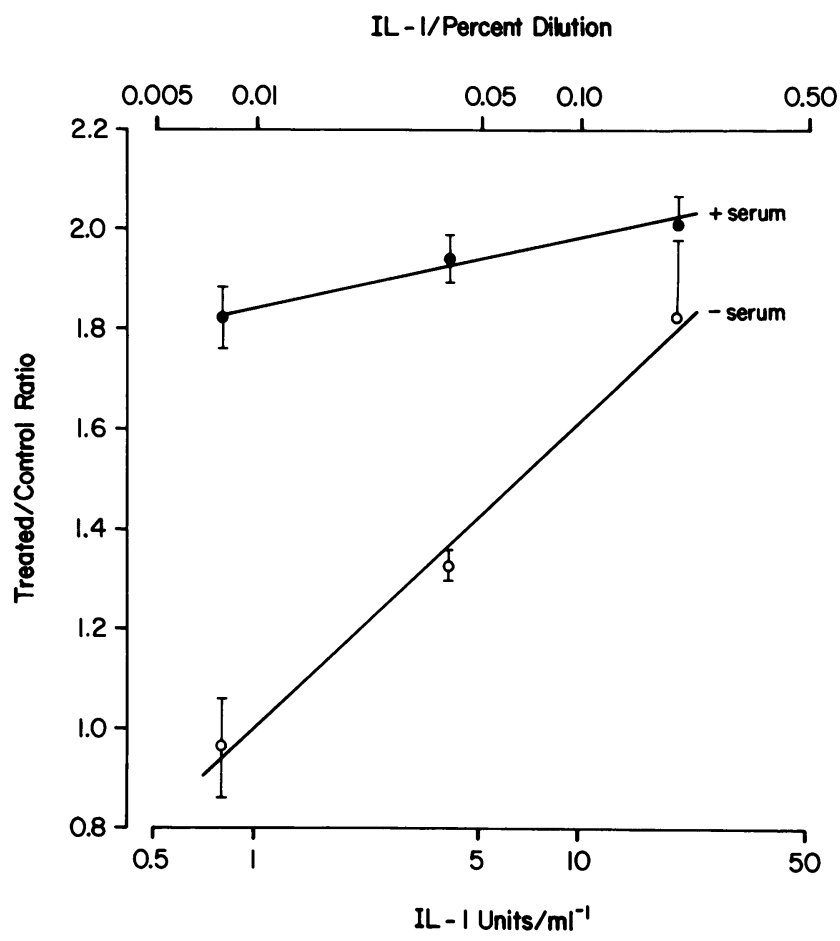

Figure 4. Stimulation of bone cell proliferation by IL-1 in the absence of serum. Cells were passaged into $1.4-\mathrm{cm}$ wells at a density of $2 \times 10^{4}$ cells/well. After $24 \mathrm{~h}$, cells were washed and the medium was replaced with MEM $+1.4 \times 10^{-6} \mathrm{M}$ indomethacin containing 15/7.1 IL-1 at the concentrations shown and $3 \%$ or no FCS. $\left[{ }^{3} \mathrm{H}\right]$ Thymidine was added for $6 \mathrm{~h}$ to two groups of cells at $66 \mathrm{~h}$. Values shown are means \pm SEM for triplicate determinations.

Because some of the activities of monocyte/macrophagederived products on cell proliferation described by other workers have been ascribed to IL-1 (19-21), fractions from two IL-1 purification steps were assayed for their capacity to stimulate bone cell proliferation. IL-1 characteristically exhibits different molecular weight species, and there is a minor peak of activity at $35,000 \mathrm{~mol}$ wt accompanying the 15,000-mol-wt peak when the IL- 1 is chromatographed by gel filtration. The higher molecular weight peak can be detected when the fractions are assayed at higher concentrations. It is subsequently diluted out leaving only the 15,000 -mol-wt peak at low concentrations.

Figs. 5 and 6 show the copurification of the thymocyteand bone cell-stimulating activities over gel filtration, both assayed at high or low dilutions. In Fig. 5, both assays were performed with a low dilution (high concentration) of the fractions, and the 15,000 and 35,000-mol-wt peaks are clear in both assays. In Fig. 6 the experiment was repeated using a high dilution (low concentration) of the fractions. The higher molecular weight peak disappeared in the thymocyte assay and is barely detectable in the bone cell assay. The two activities, therefore, display similar molecular weight characteristics.

Similarly, more than one peak of activity is detectable when IL- 1 is isoelectric focused, the predominant peak appearing at approximately neutral $\mathrm{pH}$ (isoelectric point [pI] 6.9-7.3) with a smaller peak at acid pH (pI 5.6-5.8). Comparable results were obtained when fractions from the isoelectric 

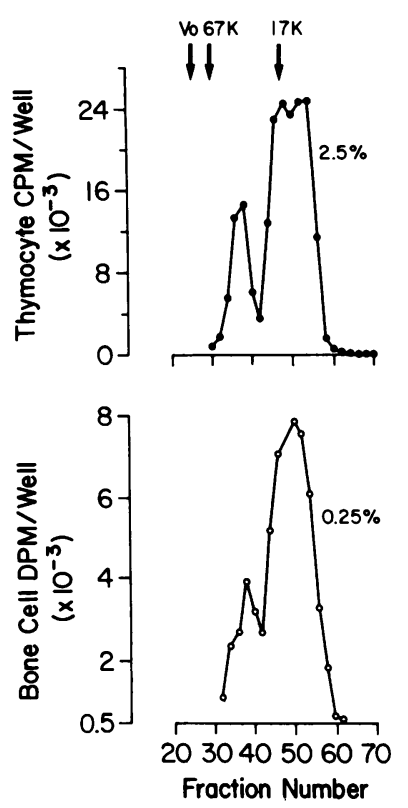

Figure 5. Copurification of bone cell-stimulating and LAF activities over G75 gel filtration chromatography. Bone cells were cultured with $0.5 \mathrm{ml} \mathrm{MEM} \mathrm{+} \mathrm{3 \%} \mathrm{FCS}$ $+1.4 \times 10^{-6} \mathrm{M}$ indomethacin containing dialyzed gel filtration fractions diluted to a concentration of $0.25 \%$. After $69 \mathrm{~h} 1 \mu \mathrm{Ci}$ $\left[{ }^{3} \mathrm{H}\right]$ thymidine was added to each well and the incubation was continued for another $6 \mathrm{~h}$. Control $\mathrm{dpm}\left[{ }^{3} \mathrm{H}\right]$ thymidine incorporation was subtracted from the values obtained for treated cells. Control incorporation was $1,760 \pm 94 \mathrm{dpm} /$ well (eight replicates). Values shown are means of four replicate determinations. LAF assays were carried out as described in the text. Values shown are means of triplicate determinations. $\mathbf{K}$, $\times 1,000$. Vo, void volume.

focusing step were tested. At a higher concentration (Fig. 7) the two isoelectric species were poorly resolved, but at a lower concentration the high pI peak was well-resolved from the less active acid pI species (Fig. 8). The cell proliferation factor, therefore, has physical properties very similar to IL-1. Finally, the dose-response to IL-1 shown in Fig. 2 highlights the wide concentration range over which the factor is active and the low doses at which proliferation can be stimulated $(\sim 0.1 \mathrm{U} /$ $\mathrm{ml}$ ). (1 $\mathrm{U}$ of IL-1 stimulates half-maximal activity in the LAF assay.)

\section{Discussion}

This study demonstrates that factors derived from human monocytes, which are similar to IL-1, are potent stimulators of the proliferation of human bone cells. These factors exhibit the same complex molecular weights and isoelectric points as IL- 1 and are active over the same concentration range.
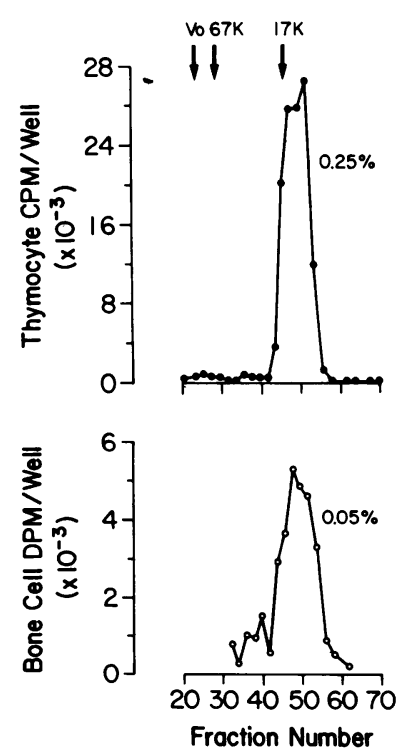

Figure 6. Copurification of bone cell-stimulating and LAF activities over G75 gel filtration chromatography. The experiment was carried out as described in the legend to Fig. 5, except that the column fractions were added at a dilution of $0.05 \%$. Control incorporation was $4,407 \pm 99 \mathrm{dpm} /$ well. $\mathrm{K}$ $\times 1,000$. Vo, void volume.
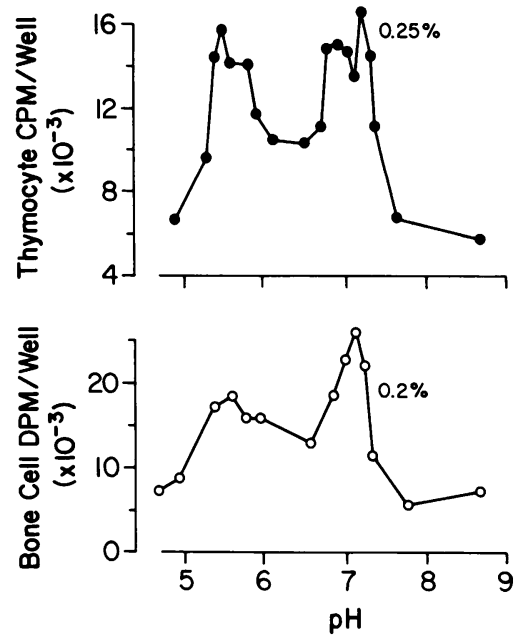

Figure 7. Copurification of bone cell-stimulating and LAF activities over isoelectric focusing. Bone cells were cultured with $0.5 \mathrm{ml} \mathrm{MEM}$ $+3 \%$ FCS $+1.4 \times 10^{-6} \mathrm{M}$ indomethacin containing dialyzed isoelectric focusing fractions at a dilution of $0.2 \%$. After $66 \mathrm{~h} 1 \mu \mathrm{Ci}$ of $\left[{ }^{3} \mathrm{H}\right]$ thymidine was added to each well and the incubation was continued for a further $6 \mathrm{~h}$. Control cells incorporated 5,418 \pm 221 $\mathrm{dpm} /$ well (12 replicates). Values shown are means \pm SEM for four replicate determinations.

These results may indicate a role for IL-1-like factors in both the degradation and repair of bone and in physiological bone remodeling. Bone-derived factors with similar molecular weights that stimulate bone cell proliferation in vitro have been described $(18,22)$, but their relationship to IL-1 has not been explored. While their cellular source has not been identified, it is conceivable that they could be synthesized by monocyte/macrophages resident in the bone. Bone differs from most other tissues in its enormous capacity for growth, continual remodeling, and repair of injury. Such activities are, naturally, under close control, but the mechanisms by which they occur are unknown. For bone remodeling to occur, osteoclastic bone resorption must be followed by a period of highly localized and limited bone formation. This process must include the recruitment of osteoblasts or their precursors to the appropriate site and their subsequent proliferation and differentiation into
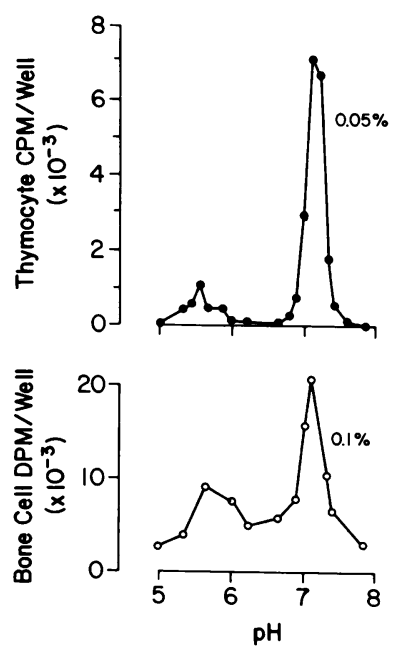

Figure 8. Copurification of bone cell-stimulating and LAF activities over isoelectric focusing. Bone cells were cultured as before with isoelectric focusing fractions at a dilution of $0.1 \%$. After $66 \mathrm{~h} 1 \mu \mathrm{Ci}$ of $\left[{ }^{3} \mathrm{H}\right]$ thymidine was added to each well and the incubation was continued for a further $6 \mathrm{~h}$. Control cells incorporated $6,388 \pm 221$ $\mathrm{dpm} /$ well (12 replicates), and this was subtracted from treated values. Values shown are means \pm SEM for four replicate determinations. 
mature, functional osteoblasts. Baron et al. (1) have recently demonstrated the arrival of mononuclear phagocytes with numerous "coated pits," thought to represent sites of specific receptors for bone matrix constituents, at the sites of resorption both before the appearance of osteoclasts and after their departure at the end of the resorption phase. The mononuclear cells that arrive after resorption could mediate some "coupling" signal between the resorbed bone surface and the osteoblast precursors. The demonstration of the release of a potent bone cell growth factor by monocytes may support such a role for the mononuclear phagocytes localized at sites of bone remodeling. If monocytes, osteoclast precursors, or osteoclasts themselves could produce such a factor in an area of resorbing bone, osteoblasts or their precursors would be activated to proliferate and thus accomplish the first stage of new bone formation. The interaction of newly recruited osteoblast precursors with bone differentiation factors, such as bone morphogenetic protein (23), could then result in new bone formation by mature osteoblasts.

IL-1 has recently been identified as a stimulator of skin fibroblast proliferation (20). These observations have been confirmed in our laboratory using partially purified IL-1 (unpublished observations). The lack of target cell specificity is not surprising and does not affect the interpretation of the results concerning bone cell proliferation. Cells with the potential for the production of such factors have been identified in highly localized sites of new bone formation where the numbers of responsive cell types would be limited. Furthermore, our observations that these factors inhibit chondrocyte proliferation (unpublished data) may reflect an important local specificity of such mitogens.

It is obviously important to identify the responding cell type(s) in these bone cell cultures. It is unlikely that all the cells in the cultures are of the same type or at the same stage of maturation. It is impossible to determine which cell types are responding to the IL-1 by an alteration in proliferation, prostaglandin production (10), collagen synthesis, and osteocalcin production (24), and how these cell types and their products interact with one another. This is true of the study of all bone-seeking hormones in bone cell metabolism, and it will, therefore, be important to separate and clone different bone cell populations and to obtain reliable markers for the various cell types.

These observations extend those by Schmidt et al. $(19,20)$ and Dayer et al. (21) who reported a stimulation of skin and synovial cell proliferation by molecules that copurified with IL-1. Because of the relevance to wound repair and diseases such as scleroderma (2), atherosclerosis (3), and granulomatous disease (4), most of the studies on macrophage-derived growth factors have been performed with skin fibroblasts, smooth muscle, and endothelial cells (5-9). It will be interesting to compare these other factors when they are purified, since they may be related to IL-1. This would implicate IL-1 in a wide range of pathological conditions.

\section{Acknowledgments}

The authors would like to thank Dr. G. Mundy for helpful discussion during the preparation of this manuscript, and Janet Gilliam and Nancy Garrett for their excellent secretarial skills.
This work was supported by the National Fund for Research into Crippling Diseases and The Leukemia Research Fund, United Kingdom.

\section{References}

1. Baron, R., P. Tran Van, and A. Vignery. 1982. Local control of bone remodelling: a suggested role for receptor-mediated endocytosis. In Current Advances in Skeletogenesis. M. Silberman and H. C. Slavkin, editors. Excerpta Medica, Amsterdam. 123-127.

2. Fleishmayer, R., J. S. Perlish, and J. R. T. Reeves. 1977. Cellular infiltrates in scleroderma skin. Arthritis Rheum. 20:975-984.

3. Gimbrone, M. A., B. M. Martin, W. A. Baldwin, E. R. Unanue, and R. S. Cotran. 1982. Stimulation of vascular cell growth by macrophage products. In Pathology of the Endothelial Cell. $\mathrm{H}$. L. Nossel and H. J. Vogel, editors. Academic Press, Inc., New York. 317.

4. Wyler, D. J., S. M. Wahl, and L. M. Wahl. 1978. Hepatic fibrosis in schistosomiasis: egg granulomas secrete fibroblast stimulating factor in vitro. Science (Wash. DC). 202:438-440.

5. Leibovich, S. J., and R. Ross. 1976. A macrophage-dependent factor that stimulates the proliferation of fibroblasts in vitro. Am. J. Pathol. 84:501-513.

6. Greenburg, G. B., and T. K. Hunt. 1978. The proliferation response in vitro of vascular endothelial cells and smooth muscle cells exposed to wound fluids and macrophages. J. Cell. Physiol. 97:353360.

7. Martin, B. M., M. A. Gimbrone, E. R. Unanue, and R. S. Cotran. 1981. Stimulation of non-lymphoid mesenchymal cell proliferation by a macrophage-derived growth factor. J. Immunol. 126: $1510-1515$.

8. Martin, B. M., M. A. Gimbrone, G. R. Majecu, E. R. Unanue, and R. S. Cotran. 1983. Stimulation of human monocyte/macrophagederived growth factor (MDGF) production by plasma fibronectin. $\mathrm{Am}$. J. Pathol. 111:367-373.

9. DeLustro, F., G. K. Sherer, and C. LeRoy. 1980. Human monocyte stimulation of fibroblast growth by a soluble mediator(s). $J$. Reticuloendothel. Soc. 28:519-532.

10. Gowen, M., D. D. Wood, E. J. Ihrie, J. E. Meats, and R. G. G. Russell. 1984. Stimulation by human interleukin 1 of cartilage breakdown and production of collagenase and proteoglycanase by human chondrocytes but not by human osteoblasts in vitro. Biochim. Biophys. Acta. 797:186-193.

11. Gowen, M., D. D. Wood, E. J. Ihrie, M. K. B. McGuire, and R. G. G. Russell. 1983. An interleukin 1 like factor stimulates bone resorption in vitro. Nature (Lond.). 306:378-380.

12. Gallagher, J. A., J. N. Beresford, M. Sharrard, M. Gowen, J. Poser, B. R. MacDonald, M. K. B. McGuire, and R. G. G. Russell. 1983. Human bone cells in culture: a novel system for the study of osteoblast function. Calcif. Tissue Int. 35(Suppl.):A24.

13. Beresford, J. N., J. A. Gallagher, J. W. Poser, and R. G. G. Russell. 1984. Synthesis of osteocalcin by human bone cells in vitro. Effects of $1,25(\mathrm{OH})_{2} \mathrm{D}_{3}$, PTH and glucocorticoids. Metab. Bone Dis. Relat. Res. 5:229-234.

14. MacDonald, B. R., J. A. Gallagher, I. Ahnfelt-Ronne, J. N. Beresford, M. Gowen, and R. G. G. Russell. 1984. Effects of bovine parathyroid hormone and 1,25-dihydroxyvitamin $D_{3}$ on the production of prostaglandins by cells derived from human bone. FEBS (Fed. Eur. Biochem. Soc.) Lett. 169:49-52.

15. Wood, D. D. 1979. Purification and properties of human Bcell activating factor. J. Immunol. 123:2395-2399.

16. Watson, J., S. Gillis, J. Marbrook, D. Mochizuki, and K. A. Smith. 1979. Biochemical and biological characterisation of lymphocyte regulatory molecules. 1 . Purification of a class of murine lymphokines. J. Exp. Med. 150:849-861. 
17. Wood, D. D. 1977. Mechanism of action of human B-cell activating factor. 1. Comparison of the plaque-stimulating activity with thymocyte-stimulating activity. J. Immunol. 123:2400-2407.

18. Shimizu, N., H. Yoshikawa, N. Takaoka, and K. Ono. 1983. Extracts of cortical bone from adult rats stimulate DNA synthesis in osteoprogenitor cells from fetal rats. Clin. Orthop. Relat. Res. 178: 252-257.

19. Schmidt, J. A., S. B. Mizel, D. Cohen, and I. Green. 1982. Interleukin 1: a potential regulator of fibroblast proliferation. J. Immunol. 128:2177-2182.

20. Schmidt, J. A., C. N. Oliver, J. L. Lepe-Zuniga, I. Green, and I. Gery. 1984. Silica-stimulated monocytes release fibroblast proliferation factors identical to interleukin 1. A potential role for interleukin 1 in the pathogenesis of silicosis. J. Clin. Invest. 73:1462-1472.
21. Dayer, J.-M., S. R. Golding, D. R. Robinson, and S. M. Krane. 1979. Effects of human mononuclear cell factor on cultured rheumatoid synovial cells. Biochim. Biophys. Acta. 586:87-105.

22. Canalis, E., W. A. Peck, and L. G. Raisz. 1980. Stimulation of DNA and collagen synthesis by autologous growth factor in cultured fetal rat calvariae. Science (Wash. DC). 210:1021-1023.

23. Urist, M. R., Y. K. Huo, A. G. Brownell, W. M. Hohl, J. Buyske, A. Lietze, P. Tempst, M. Hunkapillar, and R. J. DeLange. 1984. Purification of bovine bone morphogenetic protein by hydroxyapatite chromatography. Proc. Natl. Acad. Sci. USA. 81:371-375.

24. Gowen, M., J. N. Beresford, J. A. Gallagher, D. D. Wood, and R. G. G. Russell. 1984. Actions of interleukin 1 on bone metabolism in vitro. Calcif. Tissue Int. 35:642. (Abstr.) 